\title{
Systemy certyfikacji produktów, usług i procesów ICT na jednolitym rynku cyfrowym - ujęcie normatywne
}

\author{
Sistemas de certificación de productos, servicios y procesos TIC \\ en el Mercado Único Digital: un enfoque normativo
}

\author{
Agnieszka Żywicka \\ Uniwersytet im. Jana Kochanowskiego w Kielcach
}

\section{Wprowadzenie; identyfikacja problemu i założenia badawcze}

Zmiany społeczno-gospodarcze, w tym globalizacja gospodarki, sprawiły, że produkty cyfrowe oraz sieci i usługi łączności elektronicznej odgrywają coraz większą rolę w społeczeństwie europejskim, wspomagając funkcjonowanie rynku wewnętrznego Unii Europejskiej w różnych jego obszarach i zmieniając paradygmat funkcjonowania gospodarki. Zgodnie z nim nowy model gospodarczy ma realizować funkcjonalnie powiązane cele, obejmujące wzmocnienie efektywności i innowacyjności gospodarki oraz ochronę środowiska naturalnego poprzez zmniejszenie uzależnienia gospodarki od tradycyjnych form bezpośredniego załatwiania spraw ${ }^{1}$. Osiągnięciu powyższych zamierzeń służy jednolity rynek cyfrowy UE, ukierunkowany na zapewnienie bezpieczeństwa i niezakłóconego przebiegu transakcji zawieranych przez Internet. Mimo że owa problematyka znajduje się od kilkunastu lat w centrum zainteresowania Unii Europejskiej, prawodawca unijny dopiero niedawno dostrzegł, że w obszarze produktów cyfrowych i urządzeń podłączonych do Internetu brakowało dotychczas spójnych i precyzyjnych rozwiązań prawnych gwarantujących i potwierdzających ich bezpieczeństwo oraz odporność na różnego rodzaju zagrożenia - w tym cyberataki. Brak rozwiązań normatywnych w powyższym zakresie skutkował nieefektywnym cyberbezpieczeństwem.

Remedium na zidentyfikowane problemy są rozwiązania prawne wprowadzone Rozporządzeniem Parlamentu Europejskiego i Rady UE 2019/881 z dnia 17 kwietnia

\footnotetext{
${ }^{1}$ Por. A. Chwiałkowska, J. Kola, Wplyw ustawy o elektromobilności i paliwach alternatywnych na realizację umów na wykonanie zadania publicznego - rozważania nad spójnościa działań prawodawcy, w: Prawne i ekonomiczne aspekty rozwoju sektora elektromobilności w Polsce, red. K. Kokocińska, J. Kola, Warszawa 2019, s. 87.
} 
2019 r. w sprawie ENISA (Agencji Unii Europejskiej do spraw Cyberbezpieczeństwa) oraz certyfikacji cyberbezpieczeństwa w zakresie technologii komunikacyjnych oraz uchylenia rozporządzenia (UE) $\mathrm{nr} 526 / 2013^{2}$. Wymienionym aktem wprowadzono jednolite procedury certyfikacji produktów, usług i procesów ICT oparte na systemie oceny zgodności oraz udoskonalono sieciowe struktury nadzoru w ramach jednolitego rynku cyfrowego UE. Mając na względzie powyższą regulację, można sformułować tezę, że narzędziem prawnym służącym do zwiększenia poziomu cyberbezpieczeństwa, zagwarantowania równego dostępu do produktów i usług cyfrowych oraz budowy zaufania przedsiębiorców i konsumentów do tych produktów na jednolitym rynku cyfrowym UE jest uniwersalny system certyfikacji produktów, systemów i procesów ICT.

Cyberbezpieczeństwo jest zagadnieniem interdyscyplinarnym szeroko analizowanym w literaturze na wielu płaszczyznach naukowych oraz w wielu ujęciach ${ }^{3}$. Dla uniknięcia fragmentaryczności rozważań w niniejszym opracowaniu skoncentrowano się więc na normatywnych kwestiach kształtowania polityki cyfrowej UE (jednolitego rynku cyfrowego UE) i prawnych uwarunkowaniach gwarantowania bezpieczeństwa produktów cyfrowych z perspektywy certyfikacji.

Przy powyższych założeniach badawczych w opracowaniu poddano eksplikacji przystawalność oceny zgodności wyrobów w ujęciu systemowym (jako instytucji prawnej i technicznej) do weryfikacji jakości i bezpieczeństwa produktów, procesów i usług ICT. Wobec tak zarysowanego problemu badawczego opracowanie jest próbą udzielenia odpowiedzi na następujące pytania: Czy system oceny zgodności wyrobów jest adekwatnym narzędziem do potwierdzania bezpieczeństwa i jakości produktów cyfrowych? Czy owa regulacja spowoduje faktyczne zniesienie barier w dostępie do produktów cyfrowych dla przedsiębiorców i konsumentów i czy nie pozostanie jedynie w sferze postulatów? Jaka jest natura prawna (forma prawna) aktów prawnych (certyfikatów, deklaracji) wydawanych w procesie certyfikacji produktów, procesów i usług ICT?

${ }^{2}$ Dz. Urz. UE z 7.06.2019, L151/15.

${ }^{3}$ Wobec braku uniwersalnej definicji cyberbezpieczeństwa odsyłam do literatury przedmiotu na temat tego zjawiska, np.: C. Banasiński, Podstawowe pojęcia i podstawy prawne bezpieczeństwa w cyberprzestrzeni, w: Cyberbezpieczeństwo. Zarys wykładu, red. C. Banasiński, Warszawa 2018; J. Skrzypczak, Polityka ochrony cyberprzestrzeni RP, „Przegląd Strategiczny” 2014, nr 7, s. 133; Cybersecurity in the European Union and Beyond: Exploring the Threats and Policy Responses, Directorate - General for Internal Policies, European Union, Brussels 2015, s. 13; Z. Chmielewski, Polityka publiczna w zakresie ochrony cyberprzestrzeni w UE i państwach członkowskich, „Studia z Polityki Publicznej” 2016, nr 3, s. 103-128; Cyberbezpieczeństwo jako element bezpieczeństwa państwa i ochrony obywateli, red. J. Trubalska, Ł. Wojciechowski, Lublin 2019; M. Grzelak, K. Liedel, Bezpieczeństwo w cyberprzestrzeni. Zagrożenia i wyzwania dla Polski - zarys problemu, „Bezpieczeństwo Narodowe” 2012, nr 22, t. 2, s. 129-130; J. Stańczyk, Współczesne pojmowanie bezpieczeństwa, Warszawa 1996, s. 20; J. Wasilewski, Zarys definicyjny cyberprzestrzeni, „Przegląd Bezpieczeństwa Wewnętrznego" 2013, nr 9, s. 227. 


\section{Założenia jednolitego rynku cyfrowego UE - w poszukiwaniu genezy ram prawnych certyfikacji produktów cyfrowych}

Genezy bezpieczeństwa produktów ICT w kontekście certyfikacji należy upatrywać w ogólnej polityce cyberbezpieczeństwa UE, której założenia były fundamentami konkretnych rozwiązań prawnych w sferze certyfikacji jako narzędzia wzmacniającego bezpieczne korzystanie z tych produktów. Eksplikacja zagadnień dotyczących kształtowania jednolitej polityki cyfrowej na rynku wewnętrznym UE w zakresie bezpieczeństwa produktów, procesów i usług ICT wymaga zatem krótkiego odniesienia się $\mathrm{w}$ do katalogu zagadnień, które powinny być regulowane $\mathrm{w}$ ramach tej polityki unijnej. W literaturze wymieniane są tutaj kwestie związane $\mathrm{z}$ wielopłaszczyznowym i wielopodmiotowym zarządzaniem (governance) cyberprzestrzenią (neutralność sieciowa na rynku komunikacji elektronicznej, przydzielanie nazw i adresów w Internecie, prawa autorskie i znaki towarowe, niechciana korespondencja e-mailowa), kwestie związane z użytkownikami cyberprzestrzeni (działanie reklam zawierających złośliwe oprogramowanie, podawanie się za kogoś innego, odpowiednie korzystanie, cyberprzestępczość, geolokalizacja, prywatność, zagadnienia związane z cyberkonfliktami (kradzież własności intelektualnej, cyberszpiegostwo, cybersabotaż, cybernetyczne działania wojenne), problemy związane z infrastrukturą cyberprzestrzeni, szczegółowe problemy zarządzania cyberprzestrzenią (m.in. odpowiedzialność za powierzone dane, zarządzanie ryzykiem, certyfikowanie zawodów, zasady bezpieczeństwa, badania i rozwój) ${ }^{4}$. W ten ostatni obszar wpisuje się również zagadnienie certyfikacji systemów, usług i procesów ICT jako instrumentu zapewniającego (potwierdzającego wiarygodność) bezpieczeństwo produktów na jednolitym rynku cyfrowym ${ }^{5}$.

Polityka cyfrowa UE stanowi uszczegółowienie zidentyfikowanych powyżej problemów cyberbezpieczeństwa, ponieważ opiera się na idei jednolitego rynku cyfrowego, którego celem jest zapewnienie bezpieczeństwa transakcji dokonywanych przez Internet. Jednolity rynek cyfrowy konstrukcyjnie jest oparty na swobodach rynku wewnętrznego UE (będąc zarazem jego elementem), zatem w tych swobodach należy szukać jego założeń normatywnych. Rynek ten zmierza bowiem do wyeliminowania ograniczeń w dokonywaniu transakcji drogą elektroniczną oraz do zniesienia barier handlowych między państwami członkowskimi w celu zwiększenia dobrobytu gospodarczego i zbudowania bliskich więzi między nimi, które znajdują odzwierciedlenie w koncepcji rynku wewnętrznego określanego jako „obszar bez granic wewnętrznych, w obrębie którego zapewniony jest swobodny przepływ towa-

${ }^{4}$ Z. Chmielewski, Polityka ..., s. 109; J.L. Bayuk, J. Healey, P. Rohmeyer, M.H. Sachs, J. Schmidt, J. Weiss, Cyber Security Policy Guidebook, John Wiley \& Sons Inc., Hoboken, New Jersey 2012, s. 89.

${ }^{5}$ M. Szczygieł, Polityka cyberbezpieczeństwa Unii Europejskiej - poczatek drogi do strategicznej autonomii, „Sprawy Międzynarodowe” 2018, nr 2, s. 162-166; M. Berdel-Dudzińska, Pojęcie cyberprzestrzeni we wspótczesnym polskim porządku prawnym, „Przegląd Prawa Publicznego” 2012, nr 2, s. 23-24. 
rów, osób, usług i kapitału”. Koncepcja ta jest kontynuacją strategii „Europa 2020”, która wprowadziła europejską agendę cyfrową ${ }^{7}$ będącą jedną z siedmiu inicjatyw przewodnich, co podkreśliło kluczową rolę, którą odegrały technologie informacyjno-komunikacyjne. W Strategii jednolitego rynku cyfrowego dla Europy ${ }^{8}$ Komisja uznała ten rynek za priorytet. Problematyka zbudowania jednolitego rynku cyfrowego znalazła się również w centrum zainteresowania Parlamentu Europejskiego, który podjął $\mathrm{w}$ tym zakresie liczne inicjatywy ustawodawcze $\mathrm{w}$ formie rezolucji odnoszących się do zbudowania ram prawnych tego rynku? .

Działania organów UE wskazują, że transformacja cyfrowa spowodowała, że kształtowanie cyfrowej przyszłości Europy jest obecnie jedną z kluczowych polityk publicznych Unii Europejskiej, której celem jest zapewnienie konsumentom dostępu do bezpiecznych produktów oraz rozwój konkurencyjności jednolitego rynku cyfrowego, przy jednoczesnym zapewnieniu bezpieczeństwa usług cyfrowych jako środka służącego osiągnięciu neutralności klimatycznej do 2050 r. Unia Europejska dostrzega bowiem, że korzystanie z produktów cyfrowych, poprzez ograniczenie konieczności przemieszczania się ludzi, może korzystnie wpływać na ograniczenie emisji szkodliwych substancji do środowiska naturalnego, a tym samym sprzyjać poprawie klimatu ${ }^{10}$. Dynamicznie rozwijające się od blisko 30 lat technologie informatyczne spowodowały zniesienie wielu ograniczeń komunikacyjnych i geograficznych. Stały się podstawą złożonych systemów wspierających codzienne działania społeczne, ułatwiających funkcjonowanie gospodarek krajowych w wielu kluczowych sektorach, takich jak opieka zdrowotna, energetyka, finanse czy transport. Cyfryzacja i sieci połączeń stają się wobec tego podstawowymi ele-

${ }^{6}$ Art. 4 Traktatu o funkcjonowaniu Unii Europejskiej (wersja skonsolidowana), Dz. Urz. UE z 26.10.2012, C/326/47.

${ }^{7}$ Komunikat Komisji do Parlamentu Europejskiego, Rady, Europejskiego Komitetu Społeczno-Ekonomicznego i Komitetu Regionów Europejska agenda cyfrowa, KOM(2010)245 wersja ostateczna, Bruksela, 19.05.2010 (online), https://eur-lex.europa.eu/legal-content/PL/ALL/?uri=CELEX\%3A52010DC0245 [dostęp: 30.10.2020].

${ }^{8}$ Komunikat Komisji do Parlamentu Europejskiego, Rady, Europejskiego Komitetu Ekonomiczno-Społecznego i Komitetu Regionów Strategia jednolitego rynku cyfrowego dla Europy, COM(2015)0192, Bruksela, 6.05.2015 (online), https://eur-lex.europa.eu/legal-content/PL/ALL/?uri=celex\%3A52015DC0192 [dostęp: 31.10.2020].

${ }^{9}$ Można w tym zakresie wymienić następujące dokumenty: Rezolucja Parlamentu Europejskiego z 20.04.2012 r. w sprawie konkurencyjnego rynku cyfrowego - administracja elektroniczna jako projekt przewodni, Dz. Urz. UE z 7.09.2013, C 258/64.; Rezolucja Parlamentu Europejskiego z 4.07.2013 r. w sprawie stworzenia jednolitego rynku cyfrowego, Dz. Urz. UE z 26.02.2016, C 75/120; Rezolucja Parlamentu Europejskiego z 19.01.2016 r. w kierunku aktu o jednolitym rynku cyfrowym, Dz. Urz. UE z 12.01.2018, C 11/55; Komunikat Komisji do Parlamentu Europejskiego, Rady, Europejskiego Komitetu Społeczno-Ekonomicznego i Komitetu Regionów w sprawie umożliwienia transformacji cyfrowej opieki zdrowotnej i społecznej na jednolitym rynku cyfrowym, wzmacniania pozycji obywateli i budowania zdrowszego społeczeństwa, $\operatorname{COM}(2018) 233$, Bruksela,18.12.2019.

${ }^{10}$ Por. Konkluzje Rady w sprawie kształtowania cyfrowej przyszłości Europy, Bruksela, 9.06.2020, Dz. Urz. UE z 16.06.2020, C 202 I/1. 
mentami coraz większej liczby produktów i usług, a w wyniku nastania Internetu rzeczy w następnym dziesięcioleciu prognozowane jest zainstalowanie wyjątkowo dużej liczby połączonych urządzeń cyfrowych w Unii Europejskiej ${ }^{11}$.

Pierwszym unijnym aktem normatywnym odnoszącym się kompleksowo do problemu cyberbezpieczeństwa w obszarze infrastruktury informatycznej w ujęciu systemowym była dyrektywa Parlamentu Europejskiego i Rady (UE) 2016/1148 w sprawie środków na rzecz wysokiego wspólnego poziomu bezpieczeństwa sieci i systemów informatycznych na terytorium Unii ${ }^{12}$ (dyrektywa NIS). Dyrektywa koncentrowała się na trzech filarach: instytucjach, które powinny powstać we wszystkich państwach członkowskich, współpracy na poziomie europejskim oraz zobowiązaniach w zakresie bezpieczeństwa sieci i informacji. Zobowiązywała państwa członkowskie UE do zagwarantowania minimalnego poziomu zdolności krajowych $\mathrm{w}$ dziedzinie cyberbezpieczeństwa poprzez ustanowienie właściwych organów oraz jednolitego punktu kontaktowego ds. cyberbezpieczeństwa, powołanie zespołów reagowania na incydenty komputerowe (CSIRT) oraz przyjęcia krajowych strategii w zakresie cyberbezpieczeństwa. W dyrektywie sformułowano obowiązki służące zapewnieniu cyberbezpieczeństwa systemów informacyjnych w sektorach usług o kluczowym znaczeniu dla utrzymania krytycznej działalności społeczno-gospodarczej (energetyce, transporcie, bankowości i instytucjach finansowych, sektorach zdrowia, zaopatrzenia w wodę i infrastrukturze cyfrowej). Zgodnie z dyrektywą operatorzy najważniejszych usług zostali zobowiązani do stosowania odpowiednich zabezpieczeń, szacowania ryzyka oraz do zgłaszania właściwym organom lub CSIRT wszelkich incydentów poważnie zagrażających ich systemom informacyjnym oraz mogących znacząco zakłócić ciągłość działania usług.

Europejskie ramy certyfikacji cyberbezpieczeństwa wprowadzono rozporządzeniem Parlamentu Europejskiego i Rady (UE) 2019/881 z 17 kwietnia 2019 r. Jest to pierwsze prawo dotyczące rynku wewnętrznego, będące odpowiedzią na potrzebę podniesienia poziomu bezpieczeństwa produktów, usług i procesów ICT, które ostatecznie ma doprowadzić do zniesienia barier utrzymujących się na rynku cyfrowym poprzez wypracowanie harmonijnego podejścia do certyfikacji cyberbezpieczeństwa i umożliwienie wprowadzania systemów certyfikacji. Ogólnie rzecz ujmując, celem tej regulacji jest zapewnienie ochrony konsumentów oraz stworzenie dogodnych i konkurencyjnych warunków prowadzenia działalności gospodarczej przedsiębiorcom na rynku wewnętrznym UE. Rozporządzenie ma doprowadzić do stanu, w którym konsument będzie mógł wybierać takie urządzenia i rozwiązania, które są przetestowane i spełniają odpowiednie normy bezpieczeństwa. Z punktu widzenia podmiotów gospodarczych ma oznaczać zwiększenie swobody działalności gospodarczej na rynku wewnętrznym (oszczędność czasu i środków finansowych)

\footnotetext{
${ }^{11}$ Tamże.

${ }^{12}$ Dz. Urz. UE z 19.7.2016, L 194/1.
} 
dzięki wprowadzeniu uniwersalnego certyfikatu bezpieczeństwa usług, procesów i produktów ICT uznawanego we wszystkich państwach członkowskich. Oznacza bowiem brak obowiązku ubiegania się o certyfikat w każdym kraju, w którym przedsiębiorcy będą oferować swoje usługi bądź produkty. Certyfikacja produktów, procesów i usług ma być również instrumentem prawnym zwiększającym przewagę konkurencyjną tych podmiotów nad przedsiębiorcami, którzy nie korzystają z systemu certyfikacji.

\section{Konstrukcja normatywna oceny zgodności wyrobów z wymaganiami a swoistość europejskich programów certyfikacji cyberbezpieczeństwa - kontekst prawno-porównawczy}

Główną przyczyną certyfikacji produktów, procesów i usług ICT, którą kieruje się prawodawca unijny, jest podniesienie poziomu zaufania społeczeństwa do tych produktów poprzez zwiększenie ich bezpieczeństwa z jednej strony, z drugiej zaś poprzez wzrost konkurencyjności owych wyrobów (poddanych certyfikacji) w stosunku do innych tożsamych produktów (niemających certyfikatów). Zbliżonymi przesłankami kierował się prawodawca unijny, tworząc system oceny zgodności wyrobów z wymaganiami. Komisja UE, dążąc do wzmocnienia cyberbezpieczeństwa infrastruktur wykorzystywanych na rynku cyfrowym, zamierza podnosić wiedzę ogółu społeczeństwa na temat ryzyka w cyberprzestrzeni oraz zachęcać producentów i dostawców tych produktów do podnoszenia norm bezpieczeństwa poprzez stosowanie sprawdzonych instytucji prawnych.

Instrumentem służącym osiągnięciu powyższego zamiaru są europejskie programy certyfikacji cyberbezpieczeństwa ustanowione w rozporządzeniu nr 2019/881. Na europejski program certyfikacji cyberbezpieczeństwa składa się kompleksowy system przepisów, wymogów technicznych, norm, procedur prawnych oraz struktur instytucjonalnych ustanowionych na poziomie unijnym, mających zastosowanie do certyfikacji lub oceny zgodności określonych produktów, usług i procesów ICT. Wprowadzenie europejskich programów certyfikacji cyberbezpieczeństwa oraz potwierdzania, że dane produkty, usługi bądź procesy ICT spełniają określone wymogi bezpieczeństwa (tzw. poziom uzasadnienia zaufania), wymagało częściowej recepcji konstrukcji prawnej systemu oceny zgodności wyrobów z wymaganiami jako sprawdzonej w praktyce i funkcjonującej od kilkunastu lat w obrębie rynku wewnętrznego, instytucji służącej do weryfikacji poziomu bezpieczeństwa produktów nieżywnościowych ${ }^{13}$. Zasadna jest zatem ocena adekwatności założeń

${ }^{13}$ Ramy prawne systemu oceny zgodności określają: Decyzja Parlamentu Europejskiego i Rady nr 768/2008/WE z dnia 9.07.2008 r. w sprawie wspólnych ram dotyczących wprowadzania produktów do obrotu, Dz. Urz. UE z 13.08.2008, L 218/82, oraz Rozporządzenie Parlamentu Europejskiego i Rady WE nr 765/2008 z dnia 9.07.2008 r. ustanawiające wymagania w zakresie akredytacji i nadzoru rynku odno- 
normatywnych i konstrukcji prawnej oceny zgodności wyrobów do certyfikacji cyberbezpieczeństwa.

Instytucja systemu oceny zgodności wyrobów jest sui generis kompromisem ustawodawcy unijnego, a następnie krajowego, w godzeniu interesów konsumentów i przedsiębiorców w sferze bezpieczeństwa wyrobów. Rozpatrując termin „ocena zgodności” w znaczeniu normatywnym, należy uznać, że jest to kategoria prawa materialnego. Ocena zgodności to akt stosowania prawa właściwego podmiotu co do zgodności wyrobu z określonymi normatywnie wymaganiami. System oceny zgodności tworzą przepisy określające zasadnicze i szczegółowe wymagania dotyczące wyrobów oraz przepisy i normy określające działania podmiotów uczestniczących w procesie oceny zgodności. Zasadnicze wymagania należy pojmować jako wymagania $\mathrm{w}$ zakresie cech wyrobu, jego projektowania, konstrukcji, wytwarzania, wpływu na środowisko, działania na ludzki organizm, w tym również sposób testowania, podania lub używania, określone w przepisach UE. Pojęcie norm w systemie oceny zgodności przyjmuje natomiast swoiste znaczenie, właściwe tylko dla tej instytucji prawnej, odbiegające od jurydycznego sensu, chociaż osadzone w przepisach prawnych. Normy będące punktem odniesienia dla weryfikacji cech produktów to pozaprawne normy techniczne, utworzone w procesie normalizacji, wykorzystywane do konfrontowania poziomu bezpieczeństwa produktów z określonym wzorcem (wymaganiami) ustalonym w regulacji normatywnej ${ }^{14}$. Zgodnie z założeniami harmonizacji technicznej wymagania dla poszczególnych produktów są ustalone jednolicie w dyrektywach UE, a ich weryfikacja może być prowadzona za pomocą różnych norm technicznych. Rezultatem oceny zgodności są odpowiednie certyfikaty bezpieczeństwa i deklaracje zgodności.

Przedstawiając pokrótce mechanizm prawny oceny zgodności i zaangażowane $\mathrm{w}$ ten proces podmioty, można stwierdzić, że ocena zgodności może być przeprowadzana w rozmaity sposób. Istnieje kilka różnych metod (modułów i ich wariantów) opartych na trzech podstawowych procedurach: ocenę zgodności przeprowadza producent lub jego upoważniony przedstawiciel; jednostka notyfikowana (niezależna od dostawcy i odbiorcy) ocenia zgodność wyrobu z zasadniczymi wymaganiami; notyfikowana jednostka certyfikująca dokonuje certyfikacji - wydaje producentowi lub jego upoważnionemu przedstawicielowi certyfikat zgodności. Procedury oceny

\footnotetext{
szące się do warunków wprowadzania produktów do obrotu i uchylające rozporządzenie (EWG) nr 339/93, Dz. Urz. UE z 13.08.2008, L 218/30; Rozporządzenie Parlamentu Europejskiego i Rady (UE) 2019/1020 z dnia 20.06.2019 r. w sprawie nadzoru rynku i zgodności produktów oraz zmieniające dyrektywę 2004/42/ WE oraz rozporządzenie (WE) nr 765/2008 i (UE) nr 305/2011, Dz. Urz. UE z 25.6.2019, L169/1, które ujednoliciły mechanizmy i procedury stosowane przez państwa członkowskie w obszarze nadzoru rynku, tak aby zwiększyć skuteczność wykrywania niebezpiecznych wyrobów, wzmocnić współpracę między uczestnikami systemu nadzoru rynku, także na poziomie unijnym, oraz podnieść świadomość opinii publicznej (przedsiębiorców i konsumentów) odnośnie do korzyści i mechanizmów działania systemu.

${ }^{14}$ B. Fischer, Prawne aspekty norm technicznych. Normalizacja jako wsparcie legislacji administracyjnej, Warszawa 2017, s. 140-141.
} 
zgodności mogą dotyczyć albo samego wyrobu, albo też procesu projektowania i produkcji, mogą polegać na: wewnętrznej kontroli projektu i produkcji przez producenta; badaniu typu przez stronę trzecią (jednostkę notyfikowaną) w połączeniu z wewnętrzną kontrolą produkcji przez producenta; badaniu typu lub projektu przez stronę trzecią (jednostkę notyfikowaną) w połączeniu z zatwierdzeniem przez nią wyrobu lub systemów zapewnienia jakości produkcji lub z weryfikacją wyrobu przez stronę trzecią, weryfikacji projektu i produkcji przez stronę trzecią; zatwierdzeniu pełnego systemu kontroli jakości przez stronę trzecią.

W ogólnym kształcie normatywnym dokonanie oceny zgodności wyrobu jest obowiązkiem producenta. Producent ponosi pełną odpowiedzialność za swój wyrób, wobec tego musi kontrolować (pośrednio lub bezpośrednio) cały proces jego powstawania i zapewnić spełnienie wymagań określonych przepisami. Producent nie może scedować odpowiedzialności za wadliwy lub niebezpieczny wyrób na podwykonawcę lub jednostkę notyfikowaną. Rodzaj obowiązków producenta w zakresie dokonania oceny zgodności wyrobu zależy przede wszystkim od zastosowanego modułu.

Założenia europejskich programów certyfikacji cyberbezpieczeństwa opierają się w znacznej mierze na wyżej opisanych założeniach konstrukcyjnych przyjętych w systemie oceny zgodności wyrobów, zawierają jednak osobliwe rozwiązania prawne uwzględniające ryzyko stosowania wyrobów poddawanych tym procedurom pod względem prawdopodobieństwa wystąpienia incydentów i ich skutków. Swoistość procedury wynika przede wszystkim ze specyfiki przedmiotu, wobec którego prowadzona jest ocena, gdyż w dotychczasowym jej zastosowaniu dotyczyła ona wyrobów rozumianych jako przedmioty materialne - rzeczy ${ }^{15}$. W wypadku produktów, procesów i usług ICT sprawa wygląda jednak inaczej. Przez produkt ICT należy rozumieć element lub grupę elementów sieci lub systemów informatycznych. Usługa ICT oznacza usługę polegającą w pełni lub głównie na przekazywaniu, przechowywaniu, pobieraniu lub przetwarzaniu informacji za pośrednictwem sieci i systemów informatycznych. Proces ICT to z kolei zestaw czynności wykonywanych $\mathrm{w}$ celu projektowania, rozwijania, dostarczania lub przekazywania produktów ICT lub usług ICT. Produkty, procesy i usługi ICT ze względu na ich swoisty niematerialny aspekt wymagały wprowadzenia nowych specyficznych rozwiązań uwzględniających szczególny charakter rynku cyfrowego oraz zagrożenia, które wiążą się ze stosowaniem produktów cyfrowych. Należy przy tym zwrócić uwagę, że certyfikacja cyberbezpieczeństwa ma charakter dobrowolny, o ile prawo UE lub prawo krajowe nie stanowi inaczej. Warto zatem przyjrzeć się kilku rozwiązaniom

${ }^{15}$ W Rozporządzeniu Parlamentu Europejskiego i Rady (WE) nr 765/2008 z dnia 9.07.2008 r. ustanawiającym wymagania w zakresie akredytacji i nadzoru rynku odnoszące się do warunków wprowadzania produktów do obrotu i uchylającym rozporządzenie (EWG) nr 339/93. W art. 15 pkt 4 tego aktu czytamy, że „produkt” oznacza substancję, preparat lub produkt wytworzony w procesie produkcji niebędący produktem żywnościowym, paszą, żywym zwierzęciem lub rośliną, produktem pochodzenia ludzkiego ani produktem uzyskanym z roślin lub zwierząt związanym bezpośrednio z ich przyszłą reprodukcją. 
szczegółowym, które wprowadza rozporządzenie 2019/881 w odniesieniu do certyfikacji cyberbezpieczeństwa.

W świetle art. 54 rozporządzenia 2019/881 europejski program certyfikacji musi obejmować co najmniej następujące elementy: przedmiot, zakres i cel programu certyfikacji; odniesienie do międzynarodowych, europejskich lub krajowych standardów zastosowanych w ocenie (lub przy ich braku do specyfikacji technicznych lub wymogów cyberbezpieczeństwa określonych w programie); poziom bezpieczeństwa (poziom uzasadnienia zaufania); wskazanie, czy samoocena zgodności (tzw. ocena zgodności przez stronę pierwszą) jest dozwolona w ramach programu; szczegółowe lub dodatkowe wymogi dla jednostek oceniających zgodność; kryteria oraz metody oceny, które pozwolą wykazać, że osiągnięto wymogi bezpieczeństwa; informacje niezbędne dla procesu certyfikacji, które wnioskodawca musi udostępnić jednostkom oceniającym zgodność; jeżeli program przewiduje znaki lub etykiety określenie warunków, na jakich mogą być one używane; zasady monitorowania zgodności z wymogami certyfikatu lub unijnej deklaracji zgodności; warunki przyznawania, przedłużania i odnawiania ważności certyfikatu, a także rozszerzania lub zmniejszania zakresu certyfikacji; konsekwencje niezgodności certyfikowanych lub samoocenionych produktów, usług i procesów ICT z wymogami programu; sposoby zgłaszania i rozwiązywania wcześniej niewykrytych podatności; zasady przechowywania informacji przez jednostki oceniające zgodność; zidentyfikowane krajowe lub międzynarodowe programy certyfikacji cyberbezpieczeństwa, które obejmują te same procesy, produkty i usługi ICT; określenie treści i formatu wydawanego certyfikatu lub deklaracji zgodności.

Rozporządzenie nr 2019/881 przewiduje możliwość ustanawiania specyficznych normatywnych wymagań „poziomów uzasadnienia zaufania” produktów, procesów i usług ICT na poziomie: podstawowym, istotnym i wysokim. Głównym kryterium jest stwierdzony poziom ryzyka pod względem wystąpienia incydentów lub ich skutków związany ze stosowaniem produktu, procesu lub usługi ICT. Poziomy zaufania to kryteria bezpieczeństwa, które muszą spełniać produkty, procesy i usługi ICT (odporność na zagrożenie cyberatakami). Jednocześnie sprecyzowane zostały działania w zakresie oceny produktów, procesów i usług ICT, które mają zostać podjęte: przegląd dokumentacji technicznej, sprawdzenie i testowanie produktów w celu wykazania, że nie występują powszechnie znane podatności, oraz prawidłowe wdrożenie niezbędnej funkcjonalności bezpieczeństwa, testy sprawdzające. Europejskie certyfikaty cyberbezpieczeństwa i unijne deklaracje zgodności poza związanymi z nimi specyfikacjami technicznymi, normami i procedurami technicznymi powinny się odwoływać do owego poziomu uzasadnienia zaufania.

Oceny zgodności w ramach europejskich programów certyfikacji cyberbezpieczeństwa przeprowadzają jednostki notyfikowane, które uzyskują akredytację na podstawie rozporządzenia (WE) nr 765/2008, przy czym program może zezwolić na przeprowadzenie samooceny zgodności przez producenta (tzw. ocena zgodności 
przez stronę pierwszą). Przeprowadza ją producent lub dostawca produktów, procesów i usług ICT na swoją wyłączną odpowiedzialność. Owa ocena może dotyczyć tylko produktów, procesów i usług na podstawowym poziomie bezpieczeństwa.

Reasumując, można powiedzieć, że ocena zgodności wyrobów to konstrukcja prawna, która informuje o relacjach między produktem a określonymi normatywnie wymaganiami w wyniku przeprowadzenia procesu porównania właściwości wyrobu z określonym wzorcem ${ }^{16}$. Wskazana reguła odnosi się również do europejskich programów certyfikacji cyberbezpieczeństwa. Wdrożenie podstawowych założeń systemu oceny zgodności wyrobów do tych programów jest odpowiedzią unijnego prawodawcy na potrzebę dostosowywania już istniejących instytucji prawnych (w ujęciu poszczególnych rozwiązań normatywnych) do otaczającej rzeczywistości społecznej i gospodarczej oraz wprowadzania norm zapewniających sprawne funkcjonowanie administracji, przy jednoczesnym zabezpieczeniu jednostkom określonych pozycji wobec władzy publicznej ${ }^{17}$. Płaszczyzną odniesienia w owym procesie porównań są odpowiednie kryteria weryfikacji - wymagania zasadnicze, szczegółowe lub inne, których źródłem są normy techniczne. Przestrzeganie tych wymagań przez producenta lub dostawcę ma prowadzić do efektywnej ochrony interesu publicznego z uwzględnieniem normatywnie wyznaczonych kryteriów tej ochrony w celu zagwarantowania bezpieczeństwa produktów ${ }^{18}$. W ujęciu systemowym analizowaną instytucję należy postrzegać jako swoistego rodzaju instytucję prawną obejmującą weryfikację spełniania przez wyroby zasadniczych i innych wymagań (procedura oceny zgodności) oraz postępowanie w sprawie wprowadzonych do obrotu lub oddanych do użytku wyrobów niezgodnych z zasadniczymi lub innymi wymaganiami (nadzór rynku) ${ }^{19}$.

\section{Usuwanie barier w dostępie do produktów cyfrowych dla przedsiębiorców i konsumentów na jednolitym rynku cyfrowym. Charakter prawny certyfikatu i deklaracji}

Na jednolitym rynku w dziedzinie cyberbezpieczeństwa dotychczas zauważalna była luka w spójnym i całościowym podejściu do kwestii bezpieczeństwa: brak

${ }^{16}$ K. Kiczka, Administracyjne akty kwalifikujące w działalności gospodarczej, Wrocław 2006, s. 67.

${ }^{17}$ Por. uwagi sformułowane przez J. Jagielskiego, P. Gołaszewskiego, O problemach z prawem administracyjnym oraz niektórych węzłowych zagadnieniach tego prawa (kilka refleksji z teraźniejszej i przyszłej perspektywy), w: Prawo administracyjne dziś i jutro, red. J. Jagielski, M. Wierzbowski, Warszawa 2018, s. 30-6.

${ }^{18}$ L. Kieres, A. Borkowski, K. Kiczka, T. Kocowski, M. Guziński, M. Szydło, Instrumenty administracyjnoprawne $w$ systemie oceny zgodności, w: Instrumenty i formy prawne działania administracji gospodarczej, red. B. Popowska, K. Kokocińska, Poznań 2009, s. 229-231.

${ }^{19}$ A. Żywicka, Instrumenty administracyjnoprawne w systemie oceny zgodności - kierunki rozwoju systemu oceny zgodności, w: Prawo administracyjne dziś i jutro, red. J. Jagielski, M. Wierzbowski, Warszawa 2018, s. 283-291. 
interoperacyjnych rozwiązań (norm technicznych), praktyk i ogólnounijnych mechanizmów certyfikacji. Taki stan rzeczy generował bariery dla przedsiębiorców europejskich w konkurowaniu na poziomie krajowym, unijnym i globalnym oraz dla konsumentów, którzy nie otrzymywali uniwersalnego potwierdzenia spełniania przez produkt odpowiedniego poziomu bezpieczeństwa. Certyfikacja produktów, usług i procesów ICT była stosowana w ograniczonym stopniu, głównie na poziomie państw członkowskich lub $\mathrm{w}$ ramach programów inicjowanych przez przedsiębiorców. W rezultacie znaczenie prawne certyfikatu wydanego przez krajowy organ ds. certyfikacji cyberbezpieczeństwa nie było zasadniczo uznawane przez inne państwa członkowskie, co utrudniało porównanie w sposób obiektywny jego znaczenia na tle różnych porządków prawnych. Wprowadzenie jednolitych certyfikatów bezpieczeństwa i deklaracji zgodności uznawanych we wszystkich państwach członkowskich $\mathrm{w}$ ramach europejskich programów certyfikacji cyberbezpieczeństwa ma zatem kluczowe znaczenie w usuwaniu barier w dostępie do produktów, procesów i procesów ICT oraz w budowaniu zaufania podmiotów gospodarczych i konsumentów. Z powyższego powodu prawodawca unijny odwołuje się do poziomu „uzasadnionego zaufania” w procesie certyfikacji, wprowadzając europejski certyfikat bezpieczeństwa i europejską deklarację zgodności oraz stosując domniemanie bezpiecznego produktu ${ }^{20}$, wobec którego wydano te dokumenty. Europejski certyfikat bezpieczeństwa oraz europejska deklaracja bezpieczeństwa to instrumenty prawne bazujące na jednym z poziomów uzasadnienia zaufania będące potwierdzeniem, że produkt, proces lub usługa ICT spełniają odpowiadające temu poziomowi wymogi bezpieczeństwa.

Dokonanie oceny adekwatności opisanych instrumentów (certyfikatów i deklaracji) do osiągniętych zakreślonych celów (wymaganego poziomu bezpieczeństwa, wzrostu zaufania na rynku cyfrowym) wymaga zbadania natury prawnej tych aktów, która wywodzi się z systemu oceny zgodności z wymaganiami. Otwiera to tym

${ }^{20}$ Por. M. Wierzbowski, A. Żywicka, Prawo bezpiecznego produktu w porzadku prawnym Unii Europejskiej, w: Ustroje - Prawa człowieka - Bezpieczeństwo - Integracja europejska. Księga Jubileuszowa z okazji 70. urodzin Profesora Jerzego Jaskierni, red. R.M. Czarny, Ł. Boratyński, P. Ramiączek, K. Spryszak, Toruń 2020, s. 939-954. Pojęcie bezpiecznego produktu zawiera art. 2 lit. b dyrektywy nr 2001/95/WE. „Produktem bezpiecznym” jest produkt, który w zwykłych lub w innych, dających się w sposób uzasadniony przewidzieć, warunkach jego używania, z uwzględnieniem czasu korzystania z produktu, a także, w zależności od rodzaju produktu, sposobu uruchomienia oraz wymogów instalacji i konserwacji, nie stwarza żadnego zagrożenia lub stwarza jedynie minimalne zagrożenie, dające się pogodzić z jego zwykłym używaniem i odpowiadające wysokiemu poziomowi ochrony bezpieczeństwa i zdrowia osób. Wyraźnie wyodrębnione zostały przy tym szczegółowe kryteria, które musi spełnić produkt bezpieczny, odnoszące się do jego właściwości, łącznie z jego składem, opakowaniem, instrukcją montażu, instrukcją instalacji i konserwacji; oddziaływania na inne produkty, jeżeli można przewidzieć, że będzie on używany wraz z innymi produktami; wyglądu produktu, etykietowania, ostrzeżeń i instrukcji zastosowania i zniszczenia, a także innych wskazówek czy informacji na temat produktu. Dyrektywa 2001/95/WE Parlamentu Europejskiego i Rady z dnia 3.12.2001 r. w sprawie ogólnego bezpieczeństwa produktów, Dz. Urz. UE z 15.01.2002, L 011, P. 0004-0017. 
samym nowe perspektywy badawcze w nauce prawa publicznego gospodarczego i kierunki jego rozwoju. Ewolucja prawa gospodarczego (charakterystycznych dla niego instytucji i instrumentów prawnych) jest procesem ciągłym i nieuniknionym, ze względu na zmiany w obrębie przedmiotu jego oddziaływania, którym jest gospodarka ${ }^{21}$. Nadal niezwykle aktualne pozostaje w tej materii twierdzenie T. Rabskiej, że „cele regulacji prawnych zmieniają się wraz z narastającymi przeobrażeniami stosunków gospodarczych"22; takie przeobrażenia zachodzą w gospodarce cyfrowej. Złożony charakter współczesnych problemów w sferze stosunków społeczno-gospodarczych wywołuje potrzebę stosowania przez prawodawcę coraz to nowych instrumentów oddziaływania ${ }^{23}$, niejednokrotnie o hybrydowym charakterze ${ }^{24}$. Wraz z narastającymi zmianami stosunków społeczno-gospodarczych zmianie ulegają cele regulacji prawnych, będące podstawą aktywności ze strony organów państwa ${ }^{25}$. Uprawniona jest wobec powyższego naukowa analiza przyjętych środków oddziaływania oraz ich adekwatności do planowanych dążeń. W pierwszej kolejności należy ocenić naturę prawną certyfikatu bezpieczeństwa i deklaracji bezpieczeństwa produktów, procesów i usług ICT na płaszczyźnie prawnych form działania administracji publicznej. Czy w ogóle można traktować te akty jako prawną formę działania administracji? A jeśli tak - to gdzie je zakwalifikować w katalogu tych form? Jednoznaczna odpowiedź nie jest prosta. Konieczne jest przede wszystkim odniesienie się do obszernych - aczkolwiek niejednolitych - poglądów występujących w prawoznawstwie na temat definicji i rodzajów prawnych form działania administracji publicznej ${ }^{26}$.

Dla ustalenia istoty prawnej certyfikatu będzie pomocna definicja sformułowana przez K. Ziemskiego, według którego „przez formę prawną działania administracji rozumieć będziemy wyodrębniony bądź dający się wyodrębnić, prawem określony, o utrwalonych cechach typ czynności konwencjonalnej bądź faktycznej, bądź zespół takich czynności określonego, powołanego do wykonywania zadań z zakresu

${ }^{21}$ L. Kieres, Kierunki rozwoju regulacji publicznego prawa gospodarczego, w: 25 lat fundamentów wolności gospodarczej. Tendencje rozwojowe, red. J. Grabowski, K. Pokryszka, A. Hołda-Wydrzyńska, Katowice 2013, s. 330.

${ }^{22}$ T. Rabska, Działania administracji publicznej w świetle współczesnej koncepcji publicznego prawa gospodarczego, w: Instrumenty i formy prawne działania administracji gospodarczej, red. B. Popowska, K. Kokocińska, Poznań 2009, s. 18.

${ }^{23}$ K. Kokocińska, Prawny mechanizm prowadzenia polityki rozwoju $w$ zdecentralizowanych strukturach władzy publicznej, Poznań 2014, s. 10.

${ }^{24}$ A. Żywicka, O współzależnościach prawa publicznego i prywatnego w regulacjach gospodarczych na przykładzie systemu oceny zgodności wyrobów. Kilka refleksji, „Annales UMCS, sectio G (Ius)” 2020, nr 1, t. 67 , s. $149-161$.

${ }^{25}$ K. Kokocińska, Prawny..., s. 10.

${ }^{26}$ Poglądy na ten temat zostały obszernie przedstawione w pozycji: System prawa administracyjnego. Prawne formy działania administracji, t. 5, red. A. Błaś, J. Boć, M. Stahl, K.M. Ziemski, Warszawa 2013. Zobacz też cytowaną tam literaturę oraz K. Strzyczkowski, Uwagi o zadaniach nauki o prawnych formach działania administracji gospodarczej, w: Instrumenty..., s. 39. 
administracji publicznej podmiotu (bądź zespołu podmiotów) w celu wypełnienia zadań z zakresu administracji publicznej" ${ }^{27}$. W tym znaczeniu certyfikat można uznać za prawną formę działania administracji publicznej, nawet w przypadku wykonywania tych zadań przez podmioty prywatne (w systemie oceny zgodności często mamy do czynienia z prywatyzacją zadań publicznych).

Implikacją powyższej tezy jest kwalifikacja prawna certyfikatu. Nie jest to zadanie łatwe, zważywszy na mnogość semantyk prawnych form działania administracji publicznej wypracowanych przez doktrynę z zastosowaniem zróżnicowanych kryteriów. Na potrzeby niniejszego opracowania posłużę się koncepcją J. Starościaka, który zastosował podział na formy działania administracji w sferze wewnętrznej i zewnętrznej ${ }^{28}$. W analizowanym przypadku istotna jest sfera zewnętrzna działań administracji i dokonana w jej obrębie klasyfikacja: jednostronne akty będące władczym objawieniem woli (akty normatywne i akty administracyjne indywidualne), działania dwustronne (umowy i porozumienia), działania materialno-techniczne i czynności społeczno-organizatorskie. Na podstawie prezentowanej klasyfikacji nadal trudno jednoznacznie przesądzić o charakterze certyfikatu - czy uznać go za indywidualny akt administracyjny, czy też czynność materialno-techniczną. Akty administracyjne są szczególną formą czynności organów administrujących regulowanych przepisami prawa administracyjnego o charakterze jednostronnym i władczym, których wykonanie zapewniają liczne środki, którymi administracja dysponuje we własnym zakresie ${ }^{29}$.

W aspekcie ochrony interesu publicznego najbardziej korzystne jest zakwalifikowanie certyfikatu jako szczególnego administracyjnego aktu kwalifikującego. Pomocny będzie tutaj pogląd wyrażony przez K. Kiczkę, który za administracyjne akty kwalifikujące uznaje indywidualne działania prawne administracji publicznej, które stwierdzają (ustalają, konstatują), że rzecz (produkt) ma cechy, do których odwołuje się norma prawna. Stwierdzenie owych cech rzeczy (produktu) określonych w prawie powszechnie obowiązującym następuje przez wydanie rozstrzygnięcia administracyjnego podwójnie konkretnego, dotyczącego zawsze oznaczonego podmiotu prawa (przedsiębiorcy) oraz konkretnej formy zachowania tego podmiotu regulowanej prawem ${ }^{30}$. Instytucja systemu oceny zgodności została poddana głębokiej prywatyzacji zadań publicznych, w rezultacie tego procesu czynności w obrębie certyfikacji prowadzą jednostki notyfikowane wywodzące się spoza aparatu administracji publicznej. Taki sposób realizacji zadań publicznych nie przekreśla jednak możliwości zaliczenia certyfikatu bezpieczeństwa do grupy administracyjnych aktów kwalifikujących, które są zbliżone w swej naturze prawnej do decyzji.

${ }^{27}$ K.M. Ziemski, w: System prawa administracyjnego, t. 5, Prawne formy działania administracji, red. A. Błaś, J. Boć, M. Stahl, K.M. Ziemski, Warszawa 2013, s. 4.

${ }^{28}$ J. Starościak, Prawo administracyjne, Warszawa 1977, s. 230 i nast.

${ }^{29}$ E. Ochendowski, Prawo administracyjne, Czesść ogólna, Toruń 2004, s. 179-180.

${ }^{30}$ K. Kiczka, Administracyjne..., Wrocław 2006, s. 62. 
Certyfikat stwierdza (kwalifikuje) bowiem spełnienie przez wyrób (rzecz) konkretnych wymogów bezpieczeństwa.

Powyższy pogląd potwierdzają S. Babiarz i L. Żukowski, którzy dostrzegają, że odmowa wydania certyfikatu wynikająca z przepisów prawa wydana w procedurze przed wprowadzeniem do obrotu, z uwzględnieniem możliwości weryfikacji w postępowaniu wewnętrznym przed jednostką certyfikującą, zawiera cechy rozstrzygnięcia administracyjnego, ponieważ stwarza producentowi zakaz wprowadzania do obrotu. Tym samym zawiera elementy charakterystyczne dla procesu decyzyjnego. Przyjęcie powyższego poglądu nakazuje traktowanie czynności odmowy wydania certyfikatu zgodności jako zaskarżalnej do sądu administracyjnego, w odniesieniu do tych przypadków, w których odmowa wydania certyfikatu następowałaby przed wprowadzeniem wyrobu do obrotu ${ }^{31}$.

Inny jest natomiast charakter prawny unijnej deklaracji zgodności bezpieczeństwa. Deklaracja zgodności jest dokumentem prywatnym - oświadczeniem producenta lub jego upoważnionego przedstawiciela stwierdzającym na jego wyłączną odpowiedzialność, że wyrób jest zgodny z wymaganiami ${ }^{32}$. W tym wypadku producent lub wytwórca ponosi względem kontrahentów odpowiedzialność za brak spełniania wymogów w reżimie prywatno-prawnym. Deklarację należy zatem traktować jako powszechnie uznawany na rynku wewnętrznym dowód prywatny spełnienia przez produkt konkretnych wymogów bezpieczeństwa wskazanych w stosownych przepisach.

Przenosząc rozważania na grunt regulacji prawnych normujących certyfikację produktów, procesów i usług ICT, dostawca lub producent stwierdza, że spełnione zostały wymogi określone w europejskim programie certyfikacji, i przyjmuje odpowiedzialność za ich zgodność. Unijną deklarację zgodności oraz dokumentację techniczną należy przechowywać przez czas określony w danym europejskim programie certyfikacji. Kopię deklaracji przedkłada się do krajowego organu ds. certyfikacji cyberbezpieczeństwa i ENISA. Uniwersalny charakter deklaracji zgodności przesądza, że dokument ten w obiektywny sposób potwierdza poziom bezpieczeństwa produktów, usług i procesów ICT, co ma istotne znaczenie dla przedsiębiorców w wielu obszarach ich aktywności gospodarczej, m.in. w procedurach zamówień publicznych. Certyfikacja produktów, procesów i usług ICT jest korzystna również z punktu widzenia ochrony interesów konsumentów, zważywszy na obowiązki informacyjne, które zostały nałożone na przedsiębiorców. Producenci i dostawcy certyfikowanych produktów, procesów i usług ICT są zobowiązani do udostępniania $\mathrm{w}$ formie elektronicznej dodatkowych uzupełniających informacji na temat cyberbezpieczeństwa, które mają pomóc użytkownikom w bezpiecznej konfiguracji,

${ }^{31}$ S. Babiarz, L. Żukowski, Niektóre problemy administracyjnoprawne związane z certyfikacją zgodności wyrobów w ustawie o systemie oceny zgodności, w: Ius et lex, Księga Jubileuszowa Profesora Andrzeja Kabata, red. S. Pikulski, B. Brzeźiński, M. Goetttel, A. Biegalski, A. Goettel, D. Gibasiewicz, Olsztyn 2004, s. 43-44.

${ }^{32}$ L. Kieres, A. Borkowski, K. Kiczka, T. Kocowski, M. Guziński, M. Szydło, Instrumenty..., s. 247. 
instalacji, wdrażaniu, eksploatacji i konserwacji produktów lub usług; informacji, jak długo użytkownicy będą mieli zapewnione wsparcie bezpieczeństwa, zwłaszcza w kontekście aktualizacji związanych z cyberbezpieczeństwem; informacji na temat sposobu zgłaszania informacji o podatnościach; informacji o repozytoriach online, zwierających ujawnione luki w zabezpieczeniach danego produktu lub usługi.

\section{Podsumowanie}

Przeprowadzone w opracowaniu rozważania dotykają zaledwie kilku problemów związanych z systemem certyfikacji cyberbezpieczeństwa, czynią przedpole do dalszych badań w tej sferze. Analiza wybranych aspektów funkcjonowania jednolitego rynku cyfrowego pozwala jednak na sformułowanie następujących wniosków podsumowujących.

W warunkach gospodarki globalnej i wspólnego rynku wewnętrznego bez granic, certyfikacja produktów jest podstawowym i uniwersalnym narzędziem potwierdzania i informowania o spełnianiu różnorodnych wymagań jakościowych i bezpieczeństwa dla większości wyrobów wprowadzanych do obrotu na rynek wewnętrzny UE. Programy certyfikacji osadzone w europejskich ramach akredytacji są zatem obiektywnym narzędziem weryfikowania jakości produktów, ich uznawalność na rynku wewnętrznym zaś zapewnia swobodny przepływ towarów, przyczyniając się do znoszenia barier $\mathrm{w}$ dostępie do produktów. Wprowadzenie certyfikacji do ram prawnych jednolitego rynku cyfrowego było zatem niezbędne dla wzmocnienia bezpieczeństwa produktów, usług i procesów ICT stosowanych $\mathrm{w}$ transakcjach dokonywanych przez Internet. Jako że rynek cyfrowy jest częścią rynku wewnętrznego UE, opartego na koncepcji „obszaru bez granic wewnętrznych, w obrębie którego zapewniony jest swobodny przepływ towarów, osób, usług i kapitału", naturalną koleją rzeczy było dokonanie recepcji instytucji i instrumentów prawnych stosowanych w obszarze akredytacji wyrobów zgodnie z wymaganiami uregulowanymi w decyzji nr 768/2008/WE i rozporządzeniu UE nr 765/2008 dotyczącymi tego rynku.

Wprowadzenie programów certyfikacji cyberbezpieczeństwa wywoływało wprawdzie pewne obawy, że nowe rozwiązania prawne z miejsca podzielą rynek na tych, którzy certyfikat posiadają, i tych, którzy nie są w stanie się nim pochwalić, co może generować ryzyko wykluczenia danych podmiotów z rynku sprzeczne $\mathrm{np} . \mathrm{z}$ regulacjami o wolnym handlu ${ }^{33}$. W mojej ocenie takie obawy były bezprzedmiotowe. Certyfikacja w znacznej mierze pomaga znosić ograniczenia, głównie dzięki transparentnym i jednolitym kryteriom weryfikacji produktów, procesów i usług ICT, których punktem odniesienia są normy techniczne. Skuteczność tej

${ }^{33}$ G. Psujek, Bezpieczeństwo cyfrowe - jak je zapewnić firmom i obywatelom (online), https://cyfrowa. rp.pl/it/27074-bezpieczenstwo-cyfrowe-jak-je-zapewnic-firmom-i-obywatelom [dostęp: 9.11.2020]. 
instytucji prawnej potwierdza zresztą jej długoletnie stosowanie w stosunku do innych wyrobów na rynku wewnętrznym UE. Certyfikacja wspiera jakość oraz konkurencyjność przemysłu w sferze produktów, usług i procesów ICT, wzmacnia handel międzynarodowy, umożliwiając akceptację eksportu na całym świecie po wypełnieniu określonych wymagań technicznych. Dzięki akredytacji można mieć pewność, że wyroby dostawców spełniają wymagania rynku, oraz możliwe jest pełne zaufanie do tych wyrobów.

Odpowiadając na postawione na wstępie pytania badawcze, wprowadzony rozporządzeniem $\mathrm{nr}$ 2019/881 mechanizm weryfikacji i potwierdzania bezpieczeństwa wyrobów, procesów i usług ICT oparty na programach certyfikacji wydaje się spełniać potrzeby w zakresie potwierdzania bezpieczeństwa i zwiększania zaufania do tych produktów na jednolitym rynku cyfrowym. Wprowadzone narzędzie spełnia wymóg adekwatności i faktycznie sprzyja znoszeniu ograniczeń do produktów na jednolitym rynku cyfrowym oraz podnoszeniu poziomu zaufania do produktów cyfrowych, co wynika z powszechnej uznawalności certyfikatów i deklaracji na rynku wewnętrznym UE.

\section{Resumen extenso / Streszczenie}

Sistemas de certificación de productos, servicios y procesos TIC en el Mercado Único Digital: un enfoque normativo

Los cambios socioeconómicos, incluida la globalización de la economía, han hecho que los productos digitales y las redes y servicios de comunicaciones electrónicas desempeñen un papel cada vez más importante en la sociedad europea, apoyando el funcionamiento del mercado interior de la Unión Europea en sus diferentes ámbitos y cambiando el paradigma del funcionamiento de la economía. Conforme con él, el nuevo modelo económico ha de cumplir objetivos funcionalmente relacionados, que incluyen el fortalecimiento de la eficiencia y la innovación económica y la protección del medio ambiente, reduciendo la dependencia económica de las formas tradicionales de realizar los trámites de manera directa ${ }^{34}$. El Mercado Único Digital de la UE sirve para alcanzar estos objetivos dirigidos a garantizar la seguridad y de las transacciones realizadas de forma ininterrumpida en internet. Aunque esta problemática ha estado en el centro de interés de la Unión Europea durante varios años, el legislador de la UE se ha dado cuenta recientemente de que faltaban soluciones legales coherentes y precisas en el ámbito de los productos digitales y los

\footnotetext{
${ }^{34}$ Comparar A. Chwiałkowska, J. Kola, Wplyw ustawy o elektromobilności i paliwach alternatywnych na realizację umów na wykonanie zadania publicznego - rozważania nad spójnościa działań prawodawcy, w: Prawne i ekonomiczne aspekty rozwoju sektora elektromobilności w Polsce, red. K. Kokocińska, J. Kola, Warszawa 2019, s. 87.
} 
dispositivos conectados a internet que garantizaran y confirmaran su seguridad y resistencia a diversas amenazas, incluidos los ciberataques. La falta de soluciones normativas en este ámbito dio lugar a una ciberseguridad ineficaz.

El remedio a los problemas identificados son las soluciones legales introducidas por el Reglamento UE 2019/881 del Parlamento Europeo y del Consejo, del 17 de abril de 2019, relativo a la ENISA (Agencia de la Unión Europea para la Ciberseguridad) y a la certificación de la ciberseguridad en el ámbito de las tecnologías de la comunicación y por el que se deroga el Reglamento UE no 526/2013 ${ }^{35}$.

El Marco Europeo de Certificación de Ciberseguridad fue introducido por el Reglamento (UE) 2019/881 del Parlamento Europeo y del Consejo del 17 de abril de 2019. Es la primera ley del mercado interior que responde a la necesidad de aumentar el nivel de seguridad de los productos, servicios y procesos de las TIC, con el efecto de eliminar las barreras que persisten en el mercado digital mediante el desarrollo de un enfoque armonizado de la certificación de la ciberseguridad, que permita la introducción de los sistemas de certificación. En general, el objetivo del reglamento es garantizar la protección de los consumidores y crear condiciones empresariales favorables y competitivas para los empresarios para el desarrollo de sus actividades económicas en el mercado interior de la UE. El reglamento ha de llevar a una situación en la que los consumidores podrán elegir esos dispositivos y soluciones que han sido probados y cumplen las normas de seguridad adecuadas. Desde el punto de vista de las entidades económicas, se supone que aumentará la libertad de la actividad económica en el mercado interior (ahorro del tiempo y medios financieros), gracias a la introducción de un certificado de seguridad universal para los servicios, procesos y productos TIC, reconocido en todos los Estados miembros. Esto significa que no hay obligación de solicitar un certificado en cada país en el que los empresarios vayan a ofrecer sus servicios o productos. Se supone que la certificación de productos, procesos y servicios es también un instrumento legal que aumente la ventaja competitiva de esas entidades sobre los empresarios que no utilizan el sistema de certificación.

La razón principal de la certificación de los productos, procesos y servicios TIC, impulsada por el legislador de la UE, es aumentar el nivel de confianza de la sociedad en estos productos, mediante el aumento de su seguridad, por un lado, y por otro, el aumento de la competitividad de estos productos (sometidos a la certificación) frente a otros productos idénticos (que no posean certificados). El legislador de la UE tuvo consideraciones similares al crear el sistema de evaluación de la conformidad de los productos con los requisitos. La Comisión de la UE, intentando reforzar la ciberseguridad de las infraestructuras utilizadas en el mercado digital, pretende sensibilizar a la sociedad sobre los riesgos del ciberespacio y animar a los fabricantes y proveedores de esos productos a mejorar las normas de seguridad, utilizando

${ }^{35}$ D.O. UE del 7.06.2019, L151/15. 
instituciones jurídicas eficaces, que correspondan a las necesidades indicadas les corresponde el sistema de evaluación de la conformidad con los requisitos.

El instrumento que sirve para lograr dicha intención son los Programas Europeos de Certificación de la Ciberseguridad establecidos por el Reglamento n 2019/881. El Programa Europeo de Certificación de la Ciberseguridad consiste en un sistema completo de disposiciones, requisitos técnicos, normas, procedimientos legales y estructuras institucionales establecidas a nivel de la Unión aplicables a la certificación o evaluación de la conformidad de productos, servicios y procesos específicos de las TIC. La introducción del sistema europeo de certificación de la ciberseguridad y la confirmación de que determinados productos, servicios o procesos de las TIC cumplen determinados requisitos de seguridad (el así llamado "nivel de confianza") requería una adopción parcial de la construcción jurídica del Sistema de Evaluación de la Conformidad de los productos con los requisitos, como institución bien probada en práctica para verificar el nivel de seguridad de los productos no alimentarios, que ha estado funcionando durante varios años en el mercado interior $^{36}$, por lo tanto, es razonable evaluar la adecuación de los supuestos normativos y la construcción legal de la evaluación de la conformidad de los productos para la certificación de la ciberseguridad.

La institución del sistema de evaluación de la conformidad de los productos es un compromiso sui generis del legislador de la UE y del legislador nacional para conciliar los intereses de los consumidores y los empresarios en el ámbito de la seguridad de los productos. Los supuestos de los programas europeos de certificación de la ciberseguridad se basan en gran medida en los supuestos estructurales adoptados en el sistema de evaluación de la conformidad de los productos, sin embargo, contienen soluciones legales independientes que tienen en cuenta el riesgo de utilizar productos sujetos a esos procedimientos, en términos de probabilidad de aparición de incidentes y sus consecuencias. La especificidad del procedimiento resulta, ante todo, de la especificidad del objeto en relación con el cual se realiza la evaluación, porque en su aplicación de hasta ahora se trataba de productos enten-

${ }^{36}$ Los marcos legales del sistema de evaluación de la conformidad están definidos por: Decisión no 768/2008/CE del Parlamento Europeo y del Consejo, del 9.07.2008, sobre un marco común para la comercialización de los productos, Diario Oficial de la UE, del 13.08.2008, L 218/82 y Reglamento CE nº 765/2008 del Parlamento Europeo y del Consejo, del 9.07.2008 por el que se establecen los requisitos de acreditación y vigilancia del mercado relativos a la comercialización de los productos y por el que se deroga el Reglamento (CEE) n 339/93, Diario Oficial de la Unión Europea, del 13.08.2008, L 218/30, Reglamento (UE) 2019/1020 del Parlamento Europeo y del Consejo del 20.06.2019 relativo a la vigilancia del mercado y la conformidad de los productos y por el que se modifican la Directiva 2004/42/CE y los Reglamentos (CE) n. ${ }^{\text {7 } 765 / 2008}$ y (UE) n. ${ }^{\circ}$ 305/2011, Diario Oficial de la Unión Europea del 25.6.2019, L169/1, que unificaron los mecanismos y procedimientos aplicados por los Estados miembros en el ámbito de la vigilancia del mercado con el fin de aumentar la eficacia de la detección de los productos peligrosos, reforzar la cooperación entre los participantes en el sistema de vigilancia del mercado, también a escala de la UE, y sensibilizar a la opinión pública (empresarios y consumidores) sobre las ventajas y los mecanismos del funcionamiento del sistema. 
didos como bienes tangibles - objetos físicos ${ }^{37}$. Sin embargo, no sucede lo mismo para los productos, procesos y servicios de las TIC. Por un producto TIC se debe entender un elemento o un grupo de elementos de redes o sistemas de información. Un servicio TIC es un servicio que consiste total o principalmente en la transmisión, el almacenamiento, la recuperación o el tratamiento de la información a través de redes y sistemas de información. Un proceso TIC, en cambio, es un conjunto de actividades realizadas para el diseño, desarrollo, provisión o transferencia de productos TIC o servicios TIC. Los productos, procesos y servicios TIC, debido a su aspecto intangible específico, requerían la introducción de nuevas soluciones específicas que tuvieran en cuenta la especificidad del mercado digital y los riesgos asociados al uso de productos digitales. Cabe señalar que la certificación de la ciberseguridad es de carácter voluntario, a menos que la legislación de la UE o la legislación nacional disponga lo contrario. Por ello, merece la pena analizar algunas de las soluciones detalladas que introduce el Reglamento 2019/881 en materia de certificación de ciberseguridad.

Las evaluaciones de conformidad en el marco de los programas de certificación de ciberseguridad europeos son realizadas por organismos notificados acreditados en virtud del Reglamento (CE) n $n^{\circ} 765 / 2008$, aunque el programa puede permitir la ejecución de autoevaluación de la conformidad por parte del fabricante (la denominada evaluación de la conformidad por la primera parte). La lleva a cabo el fabricante o proveedor de productos, procesos y servicios TIC bajo su exclusiva responsabilidad. Esta evaluación sólo puede referirse a los productos, procesos y servicios del nivel básico de seguridad.

En las condiciones de una economía global y un mercado interior sin fronteras, la certificación de productos es una herramienta esencial y universal para acreditar y comunicar el cumplimiento de diversos requisitos de calidad y seguridad para la mayoría de los productos comercializados en el mercado interior de la UE. Los programas de certificación integrados en el marco europeo de acreditación constituyen, por tanto, una herramienta objetiva para la verificación de la calidad de los productos, mientras que su reconocimiento en el mercado interior garantiza la libre circulación de mercancías y contribuye a eliminar las barreras de acceso a los productos. La introducción de la certificación en el marco legal del Mercado Único Digital era, por tanto, necesaria para reforzar la seguridad de los productos, servicios y procesos TIC utilizados en las transacciones por internet. Dado que el mercado digital forma parte del mercado interior de la UE, basado en el concepto de

${ }^{37}$ En el Reglamento (CE) no 765/2008 del Parlamento Europeo y del Consejo, del 9.07.2008, por el que se establecen los requisitos de acreditación y vigilancia del mercado relativos a la comercialización de los productos y por el que se deroga el Reglamento (CEE) no 339/93. En el art. 15 punto 4 del de esta ley se puede leer que el «producto» es la sustancia, el preparado o la mercancía producidos por medio de un proceso de fabricación que no sean alimentos, piensos, plantas y animales vivos, productos de origen humano $y$ productos de origen vegetal y animal directamente relacionados con su futura reproducción. 
"un espacio sin fronteras interiores en el que está garantizada la libre circulación de mercancías, personas, servicios y capitales", era natural que las instituciones e instrumentos legales utilizados en el ámbito de la acreditación de productos con los requisitos regulados por la Decisión n 768/2008/CE y el Reglamento n 765/2008 fueran recibidos para este mercado.

\section{Bibliografia}

Babiarz S., Żukowski L., Niektóre problemy administracyjnoprawne związane z certyfikacja zgodności wyrobów w ustawie o systemie oceny zgodności, w: Ius et lex, Księga Jubileuszowa Profesora Andrzeja Kabata, red. S. Pikulski, B. Brzeźińnki, M. Goetttel, A. Biegalski, A. Goettel, D. Gibasiewicz, Olsztyn 2004.

Banasiński C., Podstawowe pojęcia i podstawy prawne bezpieczeństwa w cyberprzestrzeni, w: Cyberbezpieczeństwo. Zarys wykładu, red. C. Banasiński, Warszawa 2018.

Bayuk J.L., Healey J., Rohmeyer P., Sachs M.H., Schmidt J., Weiss J., Cyber Security Policy Guidebook, John Wiley\&Sons Inc., Hoboken, New Jersey 2012.

Berdel-Dudzińska M., Pojęcie cyberprzestrzeni we współczesnym polskim porządku prawnym, „Przegląd Prawa Publicznego" 2012, nr 2, s. 19-38.

Chmielewski Z., Polityka publiczna w zakresie ochrony cyberprzestrzeni w UE i państwach członkowskich, „Studia z Polityki Publicznej” 2016, nr 3, s. 103-128.

Chwiałkowska A., Kola J., Wpływ ustawy o elektromobilności i paliwach alternatywnych na realizacje umów na wykonanie zadania publicznego - rozważania nad spójnościa działań prawodawcy, w: Prawne i ekonomiczne aspekty rozwoju sektora elektromobilności w Polsce, red. K. Kokocińska, J. Kola, Warszawa 2019.

Cyberbezpieczeństwo jako element bezpieczeństwa państwa i ochrony obywateli, red. J. Trubalska, Ł. Wojciechowski, Lublin 2019.

Cybersecurity in the European Union and Beyond: Exploring the Threats and Policy Responses, Directorate - General for Internal Policies, European Union, Brussels 2015

Decyzja Parlamentu Europejskiego i Rady nr 768/2008/WE z dnia 9.07.2008 r. w sprawie wspólnych ram dotyczących wprowadzania produktów do obrotu, Dz. Urz. UE, z 13.08.2008, L 218/82

Dyrektywa 2001/95/WE Parlamentu Europejskiego i Rady z 3.12.2001 r. w sprawie ogólnego bezpieczeństwa produktów, Dz. Urz. z 15.01.2002, L 011, P. 0004-0017.

Fischer B., Prawne aspekty norm technicznych. Normalizacja jako wsparcie legislacji administracyjnej, Warszawa 2017.

Grzelak M., Liedel K., Bezpieczeństwo w cyberprzestrzeni. Zagrożenia i wyzwania dla Polski - zarys problemu, „Bezpieczeństwo Narodowe” 2012, nr 22, t. 2, s. 125-139.

Jagielski J., Gołaszewski P., O problemach z prawem administracyjnym oraz niektórych węzłowych zagadnieniach tego prawa (kilka refleksji z teraźniejszej i przyszłej perspektywy), w: Prawo administracyjne dziś i jutro, red. J. Jagielski, M. Wierzbowski, Warszawa 2018.

Kiczka K., Administracyjne akty kwalifikujące w działalności gospodarczej, Wrocław 2006.

Kieres L., Kierunki rozwoju regulacji publicznego prawa gospodarczego, w: 25 lat fundamentów wolności gospodarczej. Tendencje rozwojowe, red. J. Grabowski, K. Pokryszka, A. Hołda-Wydrzyńska, Katowice 2013.

Kieres L., Borkowski A. Kiczka, K., Kocowski T., Guziński M., Szydło M., Instrumenty administracyjnoprawne w systemie oceny zgodności, w: Instrumenty i formy prawne działania administracji gospodarczej, red. B. Popowska, K. Kokocińska, Poznań 2009. 
Kokocińska K., Prawny mechanizm prowadzenia polityki rozwoju w zdecentralizowanych strukturach władzy publicznej, Poznań 2014.

Komunikat Komisji do Parlamentu Europejskiego, Rady, Europejskiego Komitetu Społeczno-Ekonomicznego i Komitetu Regionów Europejska agenda cyfrowa, KOM(2010)245 wersja ostateczna, Bruksela, 19.05.2010 (online), https://eur-lex.europa.eu/legal-content/PL/ALL/?uri=CELEX\%3A52010DC0245 [dostęp:30.10.2020].

Komunikat Komisji do Parlamentu Europejskiego, Rady, Europejskiego Komitetu Ekonomiczno-Społecznego i Komitetu Regionów Strategia jednolitego rynku cyfrowego dla Europy, $\operatorname{COM}(2015) 0192$, Bruksela, 6.05 .2015 (online), https://eur-lex.europa.eu/legal-content/PL/ ALL/?uri=celex\%3A52015DC0192 [dostęp: 31.10.2020].

Komunikat Komisji do Parlamentu Europejskiego, Rady, Europejskiego Komitetu Społeczno-Ekonomicznego i Komitetu Regionów w sprawie umożliwienia transformacji cyfrowej opieki zdrowotnej i społecznej na jednolitym rynku cyfrowym, wzmacniania pozycji obywateli i budowania zdrowszego społeczeństwa, $\operatorname{COM}(2018)$ 233, Bruksela, 18.12.2019.

Ochendowski E., Prawo administracyjne, Część ogólna, Toruń 2004.

Psujek G., Bezpieczeństwo cyfrowe - jak je zapewnić firmom i obywatelom (online), https://cyfrowa.rp.pl/ it/27074-bezpieczenstwo-cyfrowe-jak-je-zapewnic-firmom-i-obywatelom, [dostęp: 9.11.2020].

Rabska T., Działania administracji publicznej w świetle współczesnej koncepcji publicznego prawa gospodarczego, w: Instrumenty i formy prawne działania administracji gospodarczej, red. B. Popowska, K. Kokocińska, Poznań 2009.

Rezolucja Parlamentu Europejskiego z 20.04.2012 r. w sprawie konkurencyjnego rynku cyfrowego administracja elektroniczna jako projekt przewodni, Dz. Urz. UE z 7.09.2013, C 258/64.

Rezolucja Parlamentu Europejskiego z 4.07.2013 r. w sprawie stworzenia jednolitego rynku cyfrowego, Dz. Urz. z 26.02.2016, C 75/120.

Rezolucja Parlamentu Europejskiego z 19.01.2016 r. w kierunku aktu o jednolitym rynku cyfrowym, Dz. Urz. UE z 12.01.2018, C 11/55.

Rozporządzenie Parlamentu Europejskiego i Rady WE nr 765/2008 z dnia 9.07.2008 r. ustanawiające wymagania w zakresie akredytacji i nadzoru rynku odnoszące się do warunków wprowadzania produktów do obrotu i uchylające rozporządzenie (EWG) nr 339/93, Dz. Urz. UE z 13.08.2008, L 218/30.

Rozporządzenie Parlamentu Europejskiego i Rady (UE) 2019/1020 z dnia 20.06.2019 r. w sprawie nadzoru rynku i zgodności produktów oraz zmieniające dyrektywę 2004/42/WE oraz rozporządzenie (WE) nr 765/2008 i (UE) nr 305/2011, Dz. Urz. UE z 25.6.2019, L169/1.

Skrzypczak J., Polityka ochrony cyberprzestrzeni RP, „Przegląd Strategiczny” 2014, nr 7, s. 133-144.

Stańczyk J., Wspótczesne pojmowanie bezpieczeństwa, Warszawa 1996.

Starościak J., Prawo administracyjne, Warszawa 1977.

Strzyczkowski K., Uwagi o zadaniach nauki o prawnych formach działaniach administracji gospodarczej, w: Instrumenty i formy prawne działania administracji gospodarczej, red. B. Popowska, K. Kokocińska, Poznań 2009.

System prawa administracyjnego. Prawne formy działania administracji, t. 5, red. A. Błaś, J. Boć, M. Stahl, K.M. Ziemski, Warszawa 2013.

Szczygieł M., Polityka cyberbezpieczeństwa Unii Europejskiej - początek drogi do strategicznej autonomii, „Sprawy Międzynarodowe” 2018, nr 2, s. 161-188.

Wasilewski J., Zarys definicyjny cyberprzestrzeni, „Przegląd Bezpieczeństwa Wewnętrznego” 2013, nr 9, s. 225-234.

Wierzbowski M., Żywicka A., Prawo bezpiecznego produktu w porządku prawnym, Unii Europejskiej, w: Ustroje - Prawa człowieka - Bezpieczeństwo - Integracja europejska. Księga jubileuszowa z okazji 70. urodzin Profesora Jerzego Jaskierni, red. R.M. Czarny, Ł. Boratyński, P. Ramiączek, K. Spryszak, Toruń 2020. 
Żywicka A., Instrumenty administracyjnoprawne w systemie oceny zgodności - kierunki rozwoju systemu oceny zgodności, w: Prawo administracyjne dziś i jutro, red. J. Jagielski, M. Wierzbowski, Warszawa 2018.

Żywicka A., O współzależnościach prawa publicznego i prywatnego w regulacjach gospodarczych na przykładzie systemu oceny zgodności wyrobów. Kilka refleksji, „Annales UMCS, sectio G (Ius)” 2020 , nr 1, t. 67, s. 149-161. 